\title{
Nitrogen Fertilization, Container Type, and Irrigation Frequency Affect Mineral Nutrient Uptake of Hydrangea
}

\author{
Tongyin Li ${ }^{1, *}$, Guihong Bi ${ }^{1}$, Xiaojie Zhao ${ }^{2}$, Richard L. Harkess ${ }^{1}$ (D) and Carolyn Scagel ${ }^{3}$ \\ 1 Department of Plant and Soil Sciences, Mississippi State University, Mississippi State, MS 39762, USA; \\ gbi@pss.msstate.edu (G.B.); richard.harkess@msstate.edu (R.L.H.) \\ 2 Department of Landscape Architecture, Hebei Agriculture University, Baoding 071001, China; \\ jessiesuzhao@hotmail.com \\ 3 U.S. Department of Agriculture, Agricultural Research Service, Horticultural Crops Research Laboratory, \\ 3420 NW Orchard Avenue, Corvallis, OR 97330, USA; carolyn.scagel@usda.gov \\ * Correspondence: t1665@msstate.edu
}

Received: 29 May 2020; Accepted: 10 July 2020; Published: 14 July 2020

\begin{abstract}
Mineral nutrient uptake of Hydrangea macrophylla 'Merritt's Supreme' affected by nitrogen $(\mathrm{N})$ fertilization rate, container type, and irrigation frequency was investigated. Rooted liners of hydrangea plants were fertilized twice weekly with a $\mathrm{N}$-free fertilizer plus five $\mathrm{N}$ rates including 0,5 , 10,15 , or $20 \mathrm{mM} \mathrm{N}$ from ammonium nitrate $\left(\mathrm{NH}_{4} \mathrm{NO}_{3}\right)$, irrigated once or twice daily with the same total irrigation volume, and grown in two types of one-gallon containers: a black plastic container and a biodegradable container (biocontainer), made from recycled paper. Concentrations of calcium (Ca) and magnesium $(\mathrm{Mg})$ averaged in the entire plant, and iron $(\mathrm{Fe})$ and manganese $(\mathrm{Mn})$ in roots had increasing trends with increasing $\mathrm{N}$ rate. By comparison, increasing $\mathrm{N}$ rate had a dilution effect on root phosphorus (P), stem and root potassium (K), stem $\mathrm{Ca}$ and $\mathrm{Mg}$, and leaf boron (B) concentrations. In general, nutrient content of each tested element increased with increasing $\mathrm{N}$ rate in each structure, or total in the plant. When there was a significant container type effect, plastic containers consistently had increased nutrient concentrations and content compared to biocontainers. One irrigation per day was beneficial in increasing nutrient concentrations of $\mathrm{P}, \mathrm{Ca}$, and zinc $(\mathrm{Zn})$ in different plant structures.
\end{abstract}

Keywords: Hydrangea macrophylla; nitrogen rate; paper biocontainer; irrigation frequency; nutrient uptake

\section{Introduction}

Hydrangea is one of the most popular ornamental crops, used as potted plants or in landscapes [1] Hydrangea macrophylla, commonly known as bigleaf or French hydrangea, is one of the most widely cultivated of over 80 species in the genus Hydrangea [2,3]. There are more than 1000 cultivars of H. macrophylla, with various shapes and sizes, and bloom colors of white, pink, blue, red, and purple [4]. In 2012, the sale value of hydrangeas as nursery stock was $\$ 91$ million in the United States, with another $\$ 30$ million sold as potted plants [5].

Hydrangeas are known to have high nutrient requirements [6,7]. Fertilization management in nursery production is largely through manipulating $\mathrm{N}$ rate because it is often considered the limiting factor. Increasing $\mathrm{N}$ rate increased plant growth index, leaf area, and plant dry weight of H. macrophylla 'Merritt's Supreme' [8]. High N fertigation rates of 210 and $280 \mathrm{mg} \cdot \mathrm{L}^{-1}$ were found to increase the number of flowers and flower size in H. macrophylla 'Merritt's Supreme' [7]. High N rate increased $\mathrm{N}$ content in H. macrophylla 'Berlin', where a good $\mathrm{N}$ status was considered important in the fall [6]. Stored $\mathrm{N}$ in the fall will be remobilized the following spring to facilitate new growth $[9,10]$. Increased $\mathrm{N}$ 
rates also increased nutrient uptake of other nutrients including $\mathrm{P}, \mathrm{K}, \mathrm{Ca}$, and $\mathrm{Mg}$ in Encore ${ }^{\circledR}$ azalea 'Chiffon' (Rhododendron sp.) [11]. Plant nutrient uptake is a function of both nutrient availability (supply) and plant growth rate (demand) [12].

An efficient and economic fertilization management strategy is closely related to irrigation management. Hydrangea plants have high water requirement and are not adept at absorbing water and nutrients from drying substrate [13]. Reduced irrigation amount, caused by biochar amendments in a pine bark substrate, was found to reduce plant dry weight of Pinky Winky ${ }^{\circledR}$ hardy hydrangea (H. paniculata) and reduce nutrient leaching [14]. Water use of H. macrophylla 'Fasan' started to decrease at a greater volumetric water content (VWC) than Gardenia jasminoides 'Radicans' $\left(0.28 \mathrm{~m}^{3} \cdot \mathrm{m}^{-3}\right.$ compared to $0.20 \mathrm{~m}^{3} \cdot \mathrm{m}^{-3}$ ). Water uptake of hydrangea ceased at a VWC of $0.16 \mathrm{~m}^{3} \cdot \mathrm{m}^{-3}$ [13]. Supplying the same amount of irrigation water through multiple irrigation events during a day to rhododendron plants was used to reduce leaching, increase nutrient uptake, or compensate for nutrient deficiencies $[15,16]$. In H. macrophylla 'Merritt's Supreme', more frequent irrigation increased plant growth index and substrate moisture, but decreased stem $\mathrm{N}$ concentration [8].

Biodegradable containers (biocontainers) have been investigated in a number of plant species and growing systems as sustainable alternatives to traditional plastic containers [17-23]. Biocontainers are constructed from a variety of materials including peat, coconut coir, feather, rice hull, recycled paper, and bioplastics $[19,24-26]$. Biocontainers of different materials have different physical and chemical properties and were shown to have different effects on plant vegetative growth, flower production, and visual quality $[24,27,28]$. Plant species vary in their growth performance when grown in different types of biocontainers. Biocontainers made from manure, straw, paper, wood fiber, and coconut fiber have porous sidewalls, and were reported to increase water use and affect nutrient uptake [29-31]. These characteristics were beneficial for Encore ${ }^{\circledR}$ azalea 'Chiffon' producing increased leaf area, biomass, and root length compared to traditional black plastic containers [32] but decreased photosynthetic rate of H. macrophylla 'Merritt's Supreme' [8]. Mineral nutrient uptake of hydrangea species grown in biocontainers has not been reported and little is known about how irrigation frequency alters hydrangea nutrition in biocontainers.

Previously we reported how $\mathrm{N}$ fertilization, container type, and irrigation frequency affected plant growth, gas exchange, and N uptake of H. macrophylla 'Merritt's Supreme' plants [8]. The effects of these factors on mineral nutrient uptake of hydrangea plants remain unclear. The objective of this study was to investigate mineral nutrient uptake of hydrangea plants affected by nitrogen rate, container type, and irrigation frequency.

\section{Materials and Methods}

Plant culture and treatments. One hundred rooted liners of H. macrophylla 'Merritt Supreme' were transplanted into two types of one-gallon containers on 1 July 2014: a black plastic container (GL 400; top diameter $17.78 \mathrm{~cm}$, bottom diameter $18.10 \mathrm{~cm}$, volume $3.785 \mathrm{~L}$; Nursery Supplies ${ }^{\circledR}$ Inc., Chambersburg, PA, USA), or a biodegradable container (biocontainer) made from a mix of recycled paper $(7 \times 7 \mathrm{RD}$; interior top diameter $18.7 \mathrm{~cm}$, bottom diameter $14.9 \mathrm{~cm}$, height $17.1 \mathrm{~cm}$, volume $3.90 \mathrm{~L}$; Western Pulp Products Co., Corvallis, OR, USA). Hydrangea plants were maintained outdoors under a shade structure with 50\% black shade cloth at the R.R. Foil Plant Science Research center of Mississippi State University in Starkville, Mississippi (USDA hardiness zone 8a; $33.4552^{\circ} \mathrm{N}, 88.7944^{\circ} \mathrm{W}$ ). A soilless substrate (Metro-Mix ${ }^{\circledR}$ 852; Sun Gro Horticulture, Agawam, MA, USA) containing about 50 to $60 \%$ composted pine bark, 30\% Sphagnum peat moss, 10\% perlite by volume, and minor amounts of vermiculite, Dolomite lime, and wetting agent was used as the growing substrate. Each hydrangea plant was fertilized with $250 \mathrm{~mL} \mathrm{~N}$-free fertilizer $\left(1.06 \mathrm{mg} \cdot \mathrm{mL}^{-1}\right.$; Cornell No. N Eq. 0-6-27; GreenCare Fertilizers, Kankakee, IL, USA) (Table S1) twice weekly plus 0, 5, 10, 15, or $20 \mathrm{mM} \mathrm{N}$ from $\mathrm{NH}_{4} \mathrm{NO}_{3}$ from 8 July to 22 September 2014. Plants were irrigated through drip irrigation either once per day at $0800 \mathrm{HR}$ or twice per day at 0800 and $1430 \mathrm{HR}$ with the same total daily irrigation volume. Plants were irrigated to replace daily water loss plus 10 to $15 \%$ leaching fraction. Irrigation volume was determined 
at four dates during the growing season approximately once per month by calculating daily water use of plants fertilized with $20 \mathrm{mM}$ grown in both container types.

Plant harvest. Each plant was destructively harvested $119 \mathrm{~d}$ after transplanting on 27 October 2014. Plant samples were cleaned free from substrate, and separated into leaf, stem, and root structures. All samples were oven dried at $60{ }^{\circ} \mathrm{C}$ to constant weight. Dry weight of each sample was recorded and used in the calculations of nutrient content in each structure type or in the entire plant. Total dry weight of a specific plant was calculated by summing the dry weight of leaves, stems, and roots. Dry weight data was reported in Li et al. [8].

Mineral nutrient concentrations. Each dry sample was ground to pass a 1-mm sieve (Wiley mini mill, Thomas Scientific, Swedesboro, NJ, USA) for mineral nutrient analyses. Dry tissue sample of $0.5 \mathrm{~g}$ was digested by $1 \mathrm{~mL}$ of $6 \mathrm{M}$ hydrochloric acid $(\mathrm{HCl})$ and $50 \mathrm{~mL}$ of $0.05 \mathrm{M} \mathrm{HCl} \mathrm{for} \mathrm{the}$ concentrations of $\mathrm{P}, \mathrm{K}, \mathrm{Ca}, \mathrm{Mg}$, Fe, Mn, $\mathrm{Zn}$, copper $(\mathrm{Cu})$, and $\mathrm{B}$ using inductively coupled plasma optical emission spectrometry (SPECTROBLUE; SPECTRO Analytical Instruments, Kleve, Germany). Plant samples were tested at the Mississippi State University Extension Service Soil Testing Laboratory. Tissue concentrations of macronutrients $\left(\mathrm{mg} \mathrm{g}^{-1}\right)$ and micronutrients $\left(\mu \mathrm{g} \mathrm{g}^{-1}\right)$ were presented on a dry weight basis.

Calculations of mineral nutrient contents. Nutrient content in each sample was calculated by multiplying dry weight of a structure (leaves, stems, or roots) by the concentration of a certain nutrient element. Total content of a given nutrient in one plant was estimated by summing the nutrient content from leaves, stems, and roots. Plant average concentration of a given nutrient was calculated by dividing the total nutrient content by total plant dry weight. Both nutrient concentration and content (mg per plant for macronutrients and $\mu$ g per plant for micronutrients) were presented in results to analyze effects of treatments on mineral nutrient uptake in the tested hydrangea cultivar.

Experimental design and data analyses. This study was set up as a factorial arrangement of treatments in a completely randomized design. The $\mathrm{N}$ rate (5 rates), container type (2 types), and irrigation frequency ( 2 frequencies) were the three main experimental factors providing 20 treatment combinations with five single-plant replications in each treatment combination. Significance of any main effect or the interaction among factors were determined by the analysis of variance (ANOVA) using the PROC GLMMIX procedure of SAS (Version 9.4; SAS Institute, Cary, NC, USA). Previous to analysis of variance, normality of data sets was confirmed using the Shapiro-Wilk's test. Where indicated by ANOVA, means were separated using Tukey's Honest Significant Difference (HSD) test at $p \leq 0.05$. When analyzing the allocation of nutrient content among leaves, stems, and roots within a plant, structure type was considered as a factor to analyze its main effect.

\section{Results}

\subsection{Macronutrient Concentrations $\left(m g g^{-1}\right)$ and Contents ( $m g$ per plant)}

Phosphorus. Concentrations and contents of $\mathrm{P}$ in leaves, stems, roots, or the entire plant was affected by the main effect of $\mathrm{N}$ rate, container type, or irrigation frequency without interactions. Greater $\mathrm{N}$ rate increased $\mathrm{P}$ uptake: phosphorus content generally increased with $\mathrm{N}$ rates from 0 to $20 \mathrm{mM}$ in leaves and in the entire plant and increased from 0 to $15 \mathrm{mM} \mathrm{N}$ in stems and roots, with $\mathrm{N}$ rates of 15 and $20 \mathrm{mM}$ resulting in similar P content (Figure S1).

Phosphorus concentrations in leaves and stems were not affected by $\mathrm{N}$ rate, averaging 2.10 and $1.67 \mathrm{mg} \mathrm{g}^{-1}$, respectively. No $\mathrm{N}$ resulted in the highest $\mathrm{P}$ concentrations of 3.66 and $2.93 \mathrm{mg} \mathrm{g}^{-1}$ among the five $\mathrm{N}$ rates in roots and averaged in plants, respectively.

Compared to the biocontainers, plastic containers increased $\mathrm{P}$ concentrations in stems, roots, and averaged in the plant by $10.3 \%, 24.8 \%$, and $11.6 \%$, respectively (Table 1 ). Plastic containers also resulted in $29.8 \%$ and $9.9 \%$ increases in P content in roots and total in the plant, respectively (Table 2 ). One irrigation per day increased P concentrations in leaves and stems by $12.3 \%$ and $7.4 \%$ compared with two irrigations per day, respectively (Table 3). 
Table 1. Container type affects concentrations of macro- and micro-nutrients in leaves, stems, roots, or averaged in the plant of H. macrophylla 'Merritt's Supreme'.

\begin{tabular}{|c|c|c|c|c|c|c|c|c|c|c|c|c|c|c|}
\hline \multirow{3}{*}{ Container Type } & \multicolumn{4}{|c|}{ Macronutrient Concentrations $\left(\mathrm{mg} \mathrm{g}^{-1}\right)^{\mathrm{z}}$} & \multicolumn{10}{|c|}{ Micronutrient Concentrations $\left(\mu \mathrm{g} \mathrm{g}^{-1}\right)$} \\
\hline & $\mathbf{P}$ & $\mathbf{P}$ & $\mathbf{P}$ & Mg & $\mathrm{Fe}$ & $\mathrm{Fe}$ & Mn & Mn & Mn & Mn & $\mathrm{Cu}$ & $\mathrm{Cu}$ & $\mathrm{Zn}$ & B \\
\hline & Stem & Root & Average & Root & Root & Average & Leaf & Stem & Root & Average & Root & Average & Root & Average \\
\hline Biocontainer & 1.59 & 2.35 & 2.16 & 1.59 & 36.3 & 42.9 & 49.2 & 32.6 & 47.4 & 46.2 & 3.78 & 2.09 & 36.6 & 25.7 \\
\hline Plastic container & 1.75 & 2.93 & 2.41 & 1.69 & 41.6 & 47.8 & 53.6 & 38.4 & 66.5 & 55.4 & 5.36 & 2.61 & 41.9 & 27.2 \\
\hline$p$-value & 0.008 & $<0.0001$ & $<0.0001$ & 0.039 & 0.0025 & 0.014 & 0.48 & 0.0001 & $<0.0001$ & $<0.0001$ & $<0.0001$ & 0.0002 & 0.0033 & 0.049 \\
\hline
\end{tabular}

Table 2. Container type affects contents of macro- and micro-nutrients in roots, or total in the plant of H. macrophylla 'Merritt's Supreme'.

\begin{tabular}{|c|c|c|c|c|c|c|c|c|c|}
\hline \multirow{3}{*}{ Container Type } & \multicolumn{3}{|c|}{ Macronutrient Content (mg Per Plant) ${ }^{\mathrm{z}}$} & \multicolumn{6}{|c|}{ Micronutrient Content ( $\mu$ g Per Plant) } \\
\hline & $\mathbf{P}$ & $\mathbf{P}$ & $\mathbf{K}$ & Mn & $\mathrm{Cu}$ & $\mathrm{Cu}$ & Zn & Zn & B \\
\hline & Root & Total & Root & Total & Root & Total & Root & Total & Root \\
\hline Biocontainer & 20.2 & 68.14 & 89.8 & 1892 & 34.9 & 60 & 350.7 & 1146 & 91.4 \\
\hline Plastic container & 26.2 & 74.91 & 112.5 & 2252 & 52.4 & 81.3 & 415 & 1308 & 103 \\
\hline$p$-value & $<0.0001$ & 0.0072 & $<0.0001$ & 0.0008 & $<0.0001$ & $<0.0001$ & 0.012 & 0.04 & 0.0028 \\
\hline
\end{tabular}

${ }^{\mathrm{z}} \mathrm{A} p$-value $\leq 0.05$ indicates significant differences within a column using the PROC GLIMMIX procedure of SAS. 
Table 3. Irrigation frequency affects nutrient concentrations in leaves, stems, or averaged in the plant of H. macrophylla 'Merritt's Supreme'.

\begin{tabular}{ccccccc}
\hline & \multicolumn{7}{c}{ Nutrient Concentrations } \\
\cline { 2 - 7 } & $\mathbf{P}$ & $\mathbf{P}$ & $\mathbf{C a}$ & $\mathbf{Z n}$ & $\mathbf{Z n}$ & $\mathbf{Z n}$ \\
\hline \multirow{2}{*}{ Irrigation Frequency $^{\mathbf{z}}$} & \multicolumn{7}{c}{$\mathbf{( m g ~ g}^{-\mathbf{1})}$} \\
& Leaf & Stem & Leaf & Leaf & $\mathbf{~ S t e m ~}$ & Average \\
\cline { 2 - 7 } & 2.21 & 1.73 & 12.1 & 32.1 & 64.2 & 39.2 \\
Once & 1.97 & 1.61 & 11.4 & 28.1 & 55.7 & 35.4 \\
Twice & 0.039 & 0.012 & 0.036 & 0.038 & 0.0047 & 0.034 \\
\hline -value & &
\end{tabular}

${ }^{\mathrm{z}}$ A $p$-value $\leq 0.05$ indicates significant differences within a column using the PROC GLIMMIX procedure of SAS.

Potassium. Greater N rate increased K uptake. Content of $\mathrm{K}$ in leaves and in the entire plant increased significantly with increasing $\mathrm{N}$ rate from 0 to $20 \mathrm{mM}$. Content of $\mathrm{K}$ in stems and roots increased with increasing $\mathrm{N}$ rate from 0 to $10 \mathrm{mM}$, with 15 and $20 \mathrm{mM} \mathrm{N}$ resulting in similar K content (Figure 1). Plastic containers increased root $\mathrm{K}$ content by $25.3 \%$ compared to biocontainers (Table 2). Irrigation frequency did not affect $\mathrm{K}$ concentration or content in any structure type or in the entire plant.
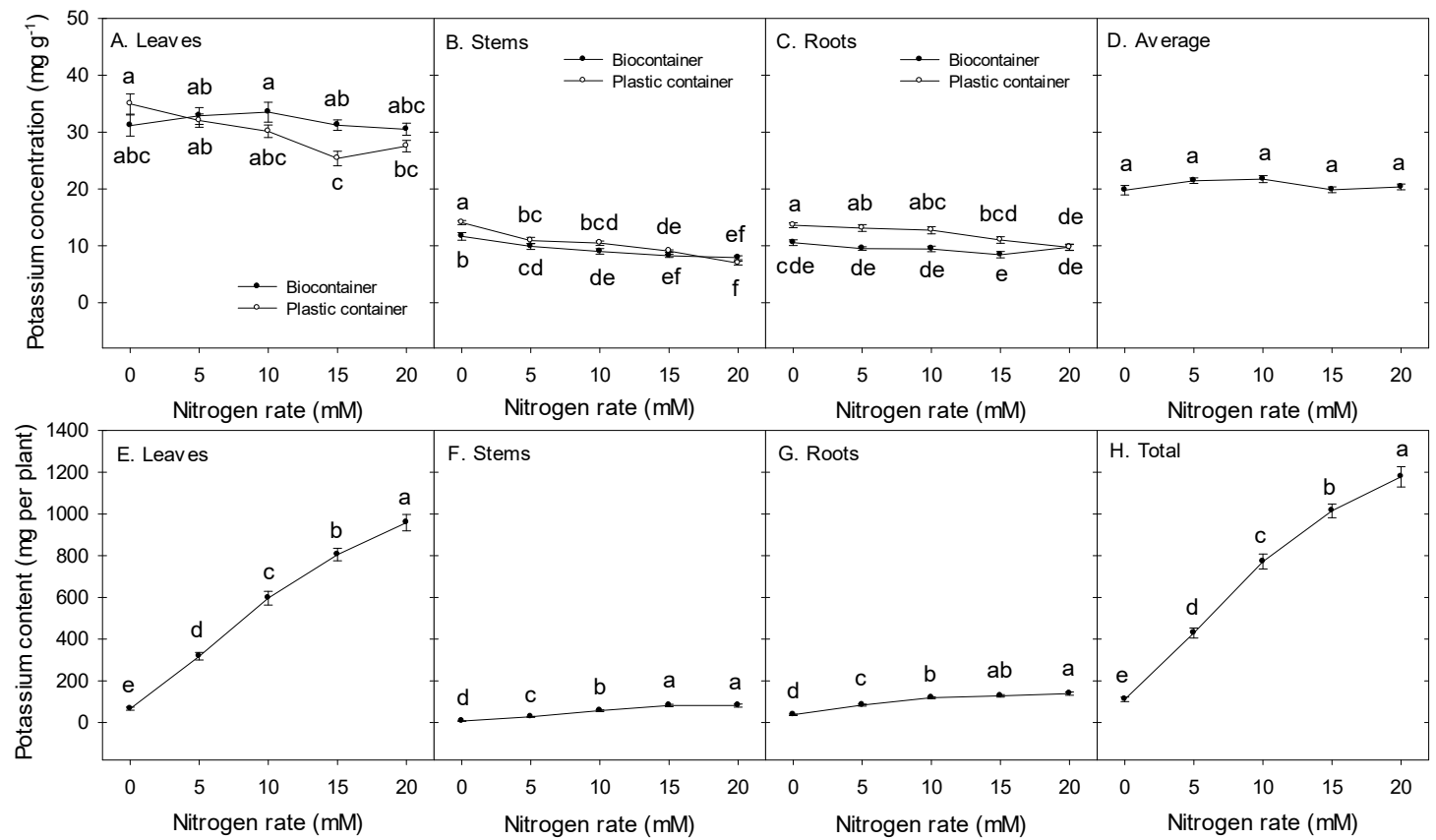

Figure 1. Concentrations ( $\mathrm{mg} \mathrm{g}^{-1}$ ) and contents (mg per plant) of potassium (K) in leaves, stems, roots, or the entire plant of H. macrophylla 'Merritt's Supreme' affected by the interaction between nitrogen $(\mathrm{N})$ rate and container type $(\mathbf{A}-\mathbf{C})$ or by the main effect of $\mathrm{N}$ rate $(\mathbf{D}-\mathbf{H})$. Data points are means $(\mathrm{A}-\mathrm{C})$ across irrigation frequencies $(n=10)$ and $(\mathbf{D}-\mathbf{H})$ across container types and irrigation frequencies $(n=20)$. Error bars are standard errors. Different lower-case letters within a chart indicate significance differences between means using Tukey's HSD test at $p$-value $\leq 0.05$.

Concentrations of $\mathrm{K}$ in leaves, stems, and roots were affected by the interaction of $\mathrm{N}$ rate and container type. Average plant $\mathrm{K}$ concentration was similar between the two container types, two irrigation frequencies, or among the five $\mathrm{N}$ rates. When affected by the $\mathrm{N}$ rate and container type interaction, concentrations of $\mathrm{K}$ were generally similar in each container type and differed little among different $\mathrm{N}$ rates. Plastic containers resulted in higher $\mathrm{K}$ concentrations than biocontainers in stems at $0 \mathrm{mM} \mathrm{N}$, and in roots at $\mathrm{N}$ rates of 0 to $15 \mathrm{mM}$, but lower $\mathrm{K}$ concentration in leaves at $15 \mathrm{mM} \mathrm{N}$.

Calcium. Content of $\mathrm{Ca}$ in stems and roots was affected by $\mathrm{N}$ rate, but not by container type or irrigation frequency. Greater $\mathrm{N}$ rate increased Ca uptake. Stem and root Ca content generally increased 
with increasing $\mathrm{N}$ rate from 0 to $15 \mathrm{mM}$ with similar content between 15 and $20 \mathrm{mM}$ N (Figure 2). Content of $\mathrm{Ca}$ in leaves and total in the plant was affected by the interaction between $\mathrm{N}$ rate and container type. When grown in biocontainers, content of $\mathrm{Ca}$ in leaves and in the entire plant increased significantly with increasing $\mathrm{N}$ rate from 0 to $20 \mathrm{mM}$. While in plastic containers, content of $\mathrm{Ca}$ in leaves and in the entire plant increased with increasing $\mathrm{N}$ rate from 0 to $15 \mathrm{mM}$, with 15 and $20 \mathrm{mM} \mathrm{N}$ resulting in similar Ca content. The two container types generally resulted in similar Ca content at a certain $\mathrm{N}$ rate in leaves and the entire plant except that biocontainers resulted in higher Ca content than plastic containers at $20 \mathrm{mM} \mathrm{N}$.
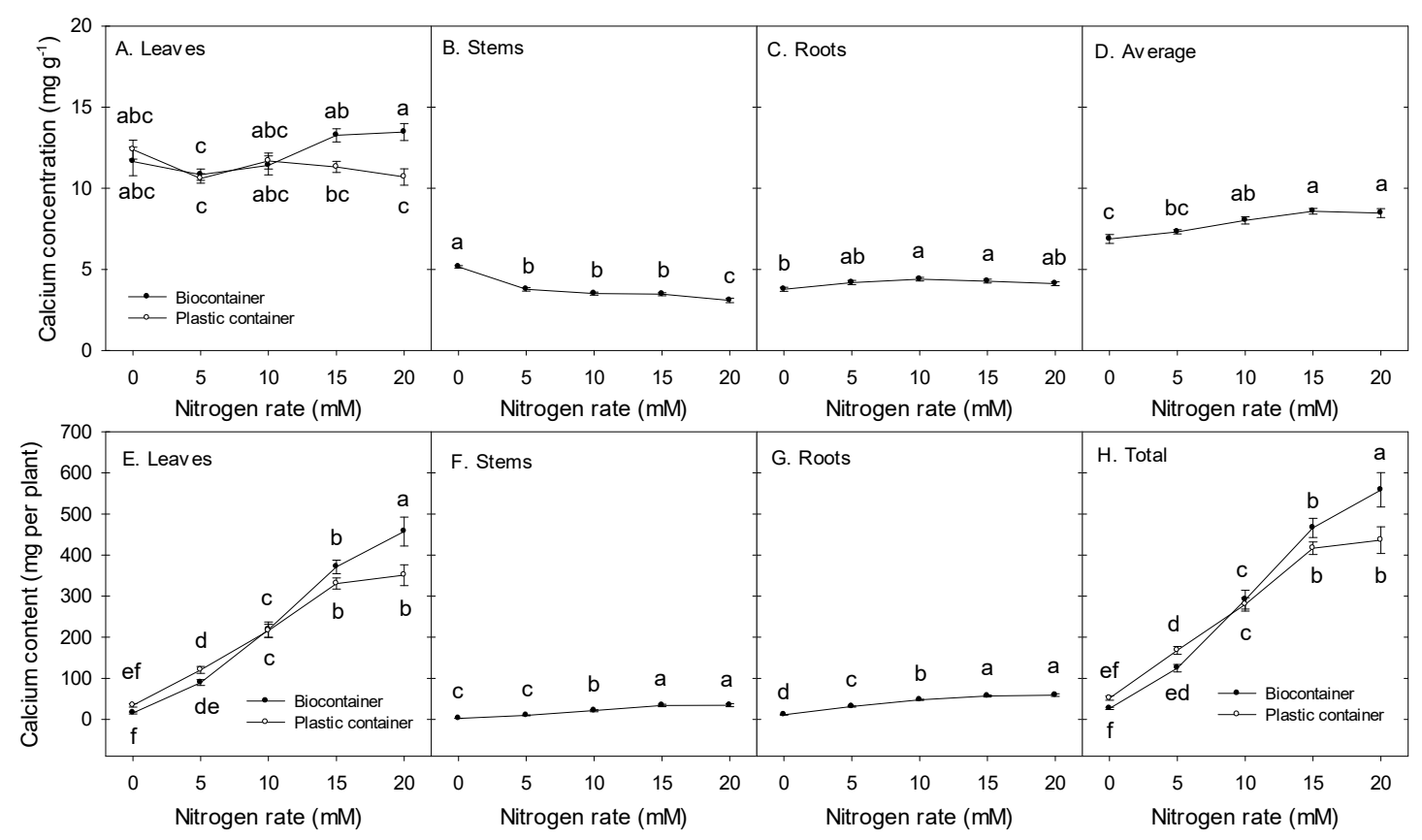

Figure 2. Concentrations ( $\mathrm{mg} \mathrm{g}^{-1}$ ) and contents (mg per plant) of Calcium (Ca) in leaves, stems, roots, or the entire plant of H. macrophylla 'Merritt's Supreme' affected by the interaction between nitrogen (N) rate and container type $(\mathbf{A}, \mathbf{E}, \mathbf{H})$ or by the main effect of $\mathrm{N}$ rate $(\mathbf{B}-\mathbf{D}, \mathbf{F}, \mathbf{G})$. Data points are means $(\mathbf{A}, \mathbf{E}, \mathbf{H})$ across irrigation frequencies $(n=10)$ and $(\mathbf{B}-\mathbf{D}, \mathbf{F}, \mathbf{G})$ across container types and irrigation frequencies $(n=20)$. Error bars are standard errors. Different lower-case letters within a chart indicate significance differences between means using Tukey's HSD test at $p$-value $\leq 0.05$.

Leaf Ca concentration was affected by the interaction between $\mathrm{N}$ rate and container type, where the five $\mathrm{N}$ rates generally resulted in similar leaf $\mathrm{Ca}$ concentration in each container type. The two container types generally resulted in similar leaf Ca concentration, except biocontainers resulted in a higher leaf $\mathrm{Ca}$ concentration than plastic containers at $20 \mathrm{mM} \mathrm{N}$. One irrigation per day increased leaf $\mathrm{Ca}$ concentration by $5.5 \%$ compared with two irrigations per day (Table 3 ).

Concentrations of $\mathrm{Ca}$ in stems, roots, and averaged in the plant were affected by $\mathrm{N}$ rate, but not by container type or irrigation frequency. No $\mathrm{N}$ resulted in the highest Ca concentration, and $20 \mathrm{mM}$ $\mathrm{N}$ resulted in the lowest Ca concentration in stems. Nitrogen rates of 5 to $20 \mathrm{mM}$ resulted in similar root Ca concentration. Average plant Ca concentration was similar among N rates of 10 to $20 \mathrm{mM}$, higher than the no $\mathrm{N}$ treatment.

Magnesium. Greater $\mathrm{N}$ rate increased $\mathrm{Mg}$ uptake. Content of $\mathrm{Mg}$ in stems and roots had an increasing trend with increasing $\mathrm{N}$ rate, with $\mathrm{N}$ rates of 15 and $20 \mathrm{mM}$ resulting in similar content (Figure 3). When affected by the interaction between $\mathrm{N}$ rate and container type, content of $\mathrm{Mg}$ in leaves and in the entire plant increased significantly with increasing $\mathrm{N}$ rate from 5 to $20 \mathrm{mM}$ in biocontainers. Whereas in plastic containers, $\mathrm{N}$ rates of 15 and $20 \mathrm{mM}$ resulted in similar Mg content in leaves or in the entire plant. As a result, biocontainers resulted in higher $\mathrm{Mg}$ content in stems and in the entire 
plant than plastic containers with $20 \mathrm{mM} \mathrm{N}$. The two container types resulted in similar Mg content in stem and the entire plant with $\mathrm{N}$ rates from 0 to $15 \mathrm{mM}$.
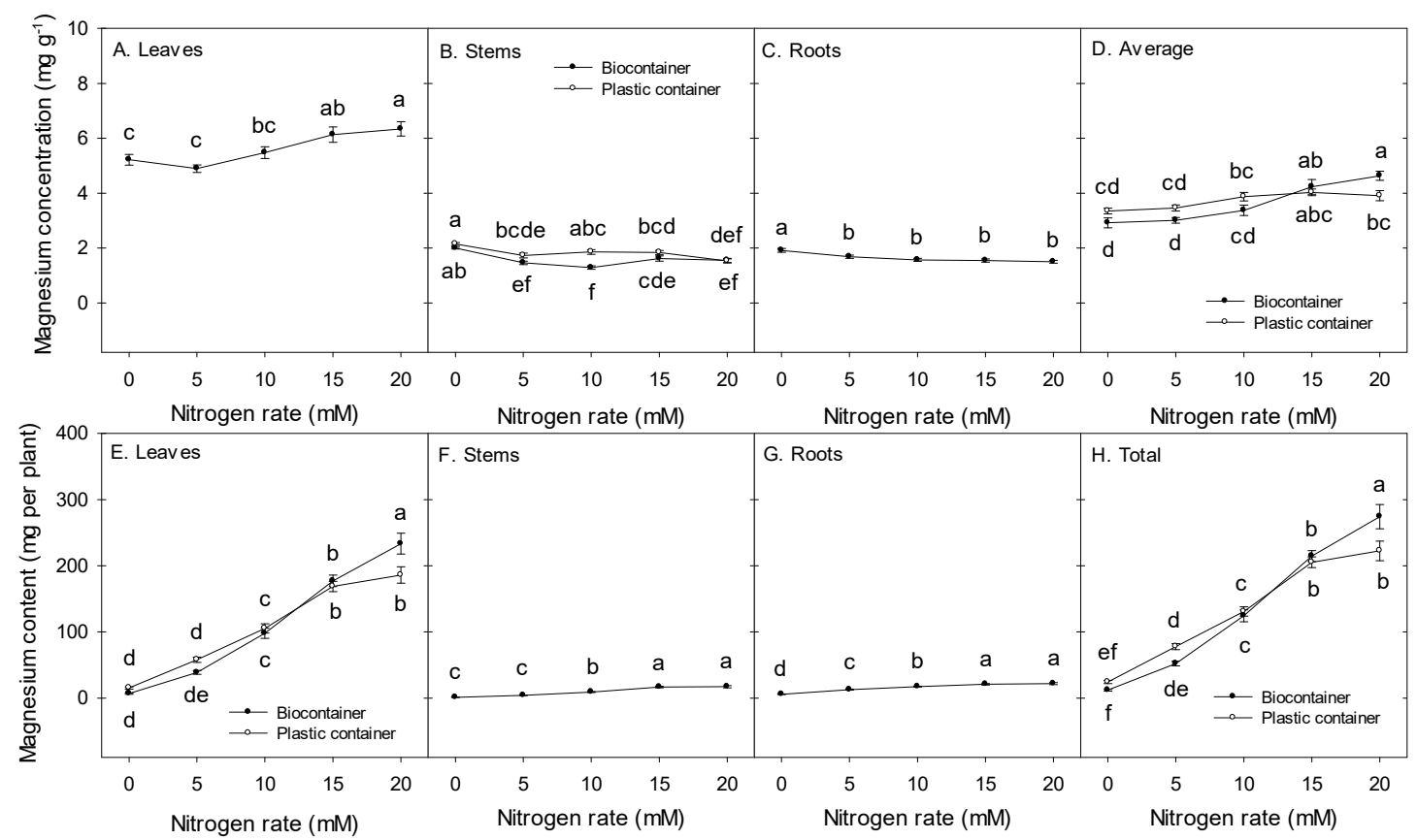

Figure 3. Concentrations ( $\mathrm{mg} \mathrm{g}^{-1}$ ) and contents (mg per plant) of Magnesium (Mg) in leaves, stems, roots, or the entire plant of H. macrophylla 'Merritt's Supreme' affected by the interaction between nitrogen $(\mathrm{N})$ rate and container type $(\mathbf{B}, \mathbf{D}, \mathbf{E}, \mathbf{H})$ or by the main effect of $\mathrm{N}$ rate $(\mathbf{A}, \mathbf{C}, \mathbf{F}, \mathbf{G})$. Data points are means $(\mathbf{B}, \mathbf{D}, \mathbf{E}, \mathbf{H})$ across irrigation frequencies $(n=10)$ and $(\mathbf{A}, \mathbf{C}, \mathbf{F}, \mathbf{G})$ across container types and irrigation frequencies $(n=20)$. Error bars are standard errors. Different lower-case letters within a chart indicate significance differences between means using Tukey's HSD test at $p$-value $\leq 0.05$.

Concentration of $\mathrm{Mg}$ in leaves and roots were affected by the main effect of $\mathrm{N}$ rate. Concentration of $\mathrm{Mg}$ in stems and averaged in the plant were affected by the interaction between $\mathrm{N}$ rate and container type. Nitrogen rates of 15 and $20 \mathrm{mM}$ resulted in higher leaf $\mathrm{Mg}$ concentrations than $\mathrm{N}$ rates of 0 or $5 \mathrm{mM}$. No $\mathrm{N}$ treatment resulted in higher root $\mathrm{Mg}$ concentration of $1.92 \mathrm{mg} \mathrm{g}^{-1}$ than $\mathrm{N}$ rates of 5 to $20 \mathrm{mM}$ with similar root $\mathrm{Mg}$ concentrations ranging from 1.5 to $1.69 \mathrm{mg} \mathrm{g}^{-1}$. Magnesium concentration in stems or averaged in the plant differed little among $\mathrm{N}$ rates within container type. The two container types generally resulted in similar $\mathrm{Mg}$ concentrations within a $\mathrm{N}$ rate, except plastic containers resulted in higher stem $\mathrm{Mg}$ concentration than biocontainers at $10 \mathrm{mM} \mathrm{N}$. Biocontainers resulted in higher average plant $\mathrm{Mg}$ concentration than plastic containers at $20 \mathrm{mM} \mathrm{N}$.

Plastic containers increased root $\mathrm{Mg}$ concentration by 6.4\% (Table 1). Irrigation frequency did not affect $\mathrm{Mg}$ concentration or content in any structure type or in the entire plant.

\subsection{Micronutrient Concentrations $\left(\mu g g^{-1}\right)$ and Contents ( $\mu g$ per plant)}

Iron. Greater $\mathrm{N}$ rate increased Fe uptake. Iron content in each structure type or total in the plant increased significantly with increasing $\mathrm{N}$ rate from 0 to $20 \mathrm{mM}$, with $20 \mathrm{mM} \mathrm{N}$ resulting in the highest Fe content (Figure S2).

Nitrogen rate of $20 \mathrm{mM}$ resulted in the highest Fe concentrations in leaves and stems, higher than those fertilized with $\mathrm{N}$ rates of 0,5 , or $10 \mathrm{mM} \mathrm{N}$ with similar Fe concentrations. In roots and averaged in the plant, Fe concentrations generally increased with increasing $\mathrm{N}$ rate, with $20 \mathrm{mM} \mathrm{N}$

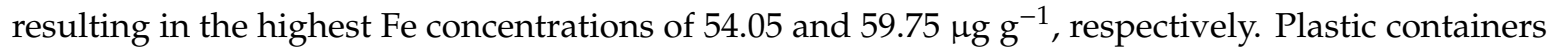
increased Fe concentrations in roots and averaged in the plant by $14.7 \%$ and $11.4 \%$, respectively 
(Table 1). Irrigation frequency did not affect Fe concentration or content in any structure type or in the entire plant.

Manganese. Greater $\mathrm{N}$ rate increased Mn uptake. Affected by the $\mathrm{N}$ rate main effect, $\mathrm{Mn}$ content increased with increasing $\mathrm{N}$ rates from 5 to $20 \mathrm{mM}$ in leaves and stems and from 0 to $20 \mathrm{mM}$ in the entire plant (Figure S3). Root Mn content was affected by the interaction between $\mathrm{N}$ rate and container type and had a generally increasing trend with increasing $\mathrm{N}$ rate in biocontainers or plastic containers. Plastic containers resulted in higher root Mn content than biocontainers at $\mathrm{N}$ rates of 15 and $20 \mathrm{mM}$.

Concentration of $\mathrm{Mn}$ in leaves, stems, roots, or averaged in the plant were affected by the main effects of $\mathrm{N}$ rate and container type without interactions. Concentration of $\mathrm{Mn}$ increased significantly with increasing $\mathrm{N}$ rate from 0 to $20 \mathrm{mM} \mathrm{N}$ in roots, from 5 to $20 \mathrm{mM} \mathrm{N}$ in leaves and averaged in the plant. Nitrogen rate of $20 \mathrm{mM}$ resulted in the highest stem Mn concentration of $53.2 \mu \mathrm{g} \mathrm{g}^{-1}$.

Plastic containers increased total Mn content and Mn concentration in leaves, stems, roots, and averaged in the plant by $19.0 \%, 9.1 \%, 17.8 \%, 28.8 \%$, and $19.9 \%$ compared to biocontainers, respectively (Tables 1 and 2). Irrigation frequency did not affect Mn concentration or content in any structure type or in the entire plant.

Copper. Greater $\mathrm{N}$ rate increased $\mathrm{Cu}$ uptake. Content of $\mathrm{Cu}$ increased with increasing $\mathrm{N}$ rate from 0 to $20 \mathrm{mM}$ in leaves, and from 0 to $15 \mathrm{mM}$ total in the plant with 15 and $20 \mathrm{mM} \mathrm{N}$ resulting in similar total plant $\mathrm{Cu}$ content (Figure 4). Root $\mathrm{Cu}$ content had an increasing trend with increasing $\mathrm{N}$ rate, with similar contents between 5 and $10 \mathrm{mM} \mathrm{N}$, or between 15 and $20 \mathrm{mM} \mathrm{N}$.
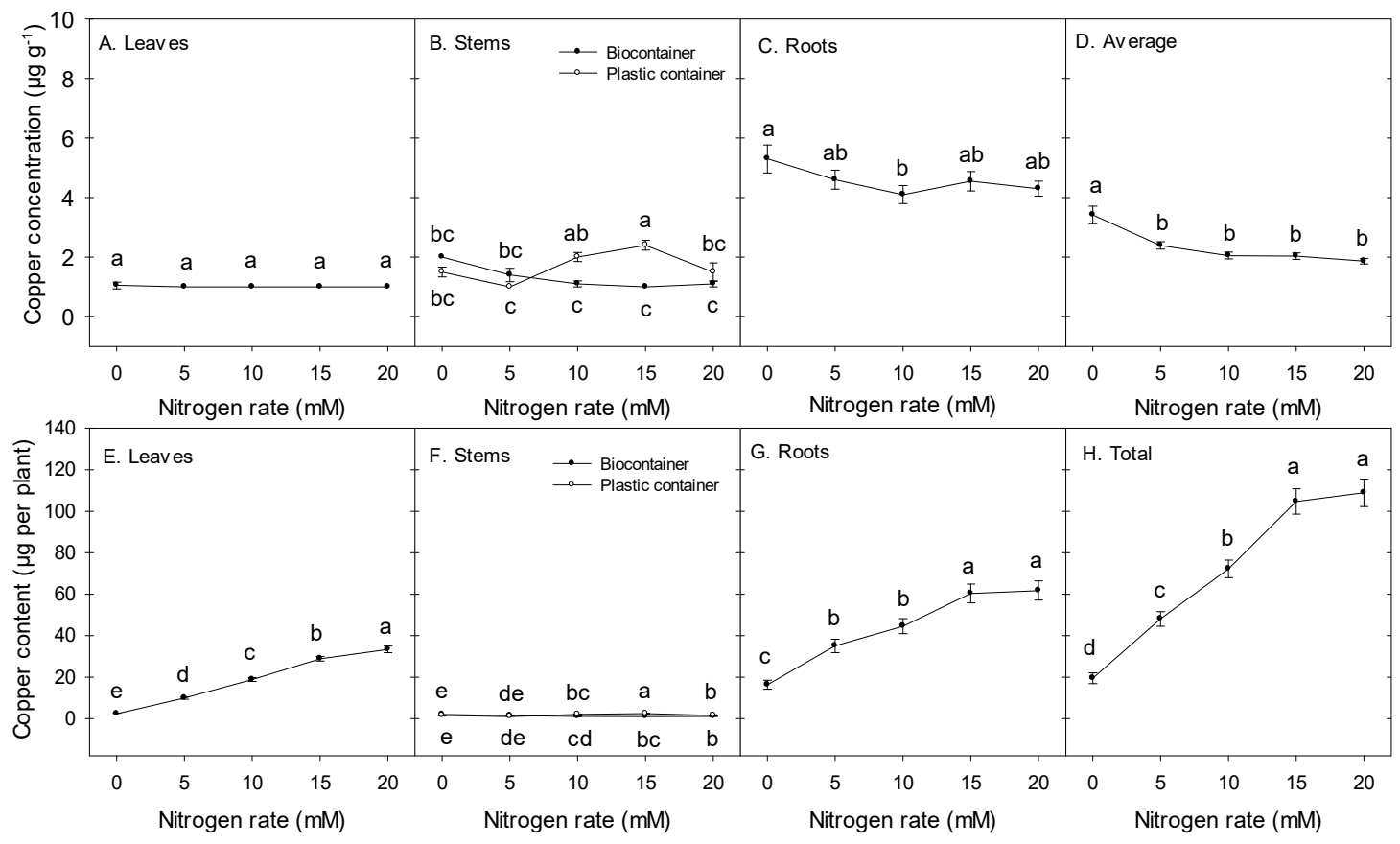

Figure 4. Concentrations $\left(\mu \mathrm{g} \mathrm{g}^{-1}\right)$ and contents ( $\mu \mathrm{g}$ per plant) of copper $(\mathrm{Cu})$ in leaves, stems, roots, or the entire plant of $H$. macrophylla 'Merritt's Supreme' affected by the main effect of nitrogen (N) rate $(\mathbf{A}, \mathbf{C}-\mathbf{E}, \mathbf{G}, \mathbf{H})$ or by the interaction between $\mathrm{N}$ rate and container type $(\mathbf{B}, \mathbf{F})$. Data points are means $(\mathbf{B}, \mathbf{F})$ across irrigation frequencies $(n=10)$ and $(\mathbf{A}, \mathbf{C}-\mathbf{E}, \mathbf{G}, \mathbf{H})$ across container types and irrigation frequencies $(n=20)$. Error bars are standard errors. Different lower-case letters within a chart indicate significance differences between means using Tukey's HSD test at $p$-value $\leq 0.05$.

Stem $\mathrm{Cu}$ concentration and content were affected by the interaction between $\mathrm{N}$ rate and container type. Plants fertilized with $15 \mathrm{mM} \mathrm{N}$ grown in plastic containers had the highest stem Cu concentration and content among all treatment combinations. The two container types generally resulted in similar $\mathrm{Cu}$ concentrations or content within a certain $\mathrm{N}$ rate except plastic containers resulted in higher stem Cu concentration at 10 and $15 \mathrm{mM} \mathrm{N}$ and higher stem Cu content at $15 \mathrm{mM} \mathrm{N}$. 
Leaf $\mathrm{Cu}$ concentration was similar among $\mathrm{N}$ rate, container type, or irrigation frequency. Concentration of $\mathrm{Cu}$ in roots and averaged in plant was affected by the main effects of $\mathrm{N}$ rate and container type without interactions. Nitrogen rates of 5 to $20 \mathrm{mM}$ resulted in similar $\mathrm{Cu}$ concentrations in leaves and averaged in plant.

Plastic containers increased $\mathrm{Cu}$ concentration in roots and averaged in the plant and increased $\mathrm{Cu}$ content in roots and total in the plant by $41.8 \%, 25.1 \%, 50.2 \%$, and $35.5 \%$ compared with biocontainers, respectively (Tables 1 and 2). Irrigation frequency did not affect $\mathrm{Cu}$ concentration or content in any structure type or in the entire plant.

Zinc. Greater $\mathrm{N}$ rate increased $\mathrm{Zn}$ uptake. Content of $\mathrm{Zn}$ in each structure or total in the plant increased significantly with increasing $\mathrm{N}$ rate, except 10 and $15 \mathrm{mM} \mathrm{N}$ resulted in similar root $\mathrm{Zn}$ content (Figure S4).

Concentration of $\mathrm{Zn}$ in stems, roots, or averaged in the plant were similar among different $\mathrm{N}$ rates. Leaf $\mathrm{Zn}$ concentration was similar among $\mathrm{N}$ rates from 5 to $20 \mathrm{mM}$, with $0 \mathrm{mM} \mathrm{N}$ resulting in the highest leaf $\mathrm{Zn}$ concentration of $38.9 \mu \mathrm{g} \mathrm{g}^{-1}$.

Plastic containers increased root $\mathrm{Zn}$ concentration, root $\mathrm{Zn}$ content, and total plant $\mathrm{Zn}$ content by $14.5 \%, 18.3 \%$ and $14.1 \%$, respectively (Tables 1 and 2). One irrigation per day increased concentration of $\mathrm{Zn}$ in leaves, stems, and averaged in the plant by $14.4 \%, 15.1 \%$, and $10.8 \%$, respectively (Table 3).

Boron. Greater N rate increased B uptake. Content of B in each structure type or total in the plant generally increased with increasing $\mathrm{N}$ rate from 0 to $20 \mathrm{mM} \mathrm{N}$, except 15 and $20 \mathrm{mM}$ N resulted in similar B content in stems (Figure S5).

Boron concentration in leaves and stems had a decreasing trend with increasing $\mathrm{N}$ rate, with no $\mathrm{N}$ treatment resulting in the highest B concentration of $55.05 \mu \mathrm{g} \mathrm{g}^{-1}$ and $15 \mu \mathrm{g} \mathrm{g}^{-1}$ in leaves and stems, respectively. Average plant $\mathrm{B}$ concentration was similar among all $\mathrm{N}$ rates.

Root $\mathrm{B}$ concentration was affected by the interaction between $\mathrm{N}$ rate and container type with the two containers generally resulting in similar $\mathrm{B}$ concentrations at a certain $\mathrm{N}$ rate except that plastic containers resulted in higher root $\mathrm{B}$ concentration than biocontainers at 10 and $15 \mathrm{mM} \mathrm{N}$. In each container type, there was not much separation of root $\mathrm{B}$ concentration among the five $\mathrm{N}$ rates.

Plastic containers resulted in higher B concentration averaged in the plant and higher root $\mathrm{B}$ content than biocontainers by $6.2 \%$ and $12.7 \%$, respectively (Tables 1 and 2 ). Irrigation frequency did not affect B concentration or content in any structure or the entire plant.

Allocation of nutrient contents in different structures. For eight of the tested mineral nutrients including $\mathrm{P}, \mathrm{K}, \mathrm{Ca}, \mathrm{Mg}, \mathrm{Fe}, \mathrm{Mn}, \mathrm{Zn}$, and $\mathrm{B}$, highest accumulations were in leaves, followed by roots, with stems having the lowest mineral nutrient contents among the three structures (Table 4). Leaves had $26.3 \%$ (in $\mathrm{Cu}$ ) to $82.5 \%$ (in B) of total mineral nutrient content in the entire plant. Highest $\mathrm{Cu}$ content was found in roots, $61.8 \%$ of total $\mathrm{Cu}$ content, with leaves being the second and stems having the lowest $\mathrm{Cu}$ content.

Table 4. Allocation of macro- and micro-nutrient contents among leaves, stems, and roots within $H$. macrophylla 'Merritt's Supreme'.

\begin{tabular}{|c|c|c|c|c|c|c|c|c|c|}
\hline & \multicolumn{4}{|c|}{ Macronutrient Content (mg Per Plant) ${ }^{\mathrm{z}}$} & \multicolumn{5}{|c|}{ Micronutrient Content ( $\mu \mathrm{g}$ Per Plant) } \\
\hline & $\mathbf{P}$ & $\mathbf{K}$ & $\mathrm{Ca}$ & Mg & $\mathrm{Fe}$ & Mn & $\mathrm{Cu}$ & $\mathrm{Zn}$ & B \\
\hline Leaf & $38.9 \mathrm{a}$ & $548.7 \mathrm{a}$ & $220.4 \mathrm{a}$ & $108.6 \mathrm{a}$ & $1087 \mathrm{a}$ & $1211 \mathrm{a}$ & $18.6 \mathrm{~b}$ & $519.7 \mathrm{a}$ & $740.1 \mathrm{a}$ \\
\hline Stem & $9.4 \mathrm{c}$ & $51.3 \mathrm{c}$ & $20.4 \mathrm{c}$ & $9.6 \mathrm{c}$ & $216.8 \mathrm{c}$ & $240 \mathrm{c}$ & $8.4 \mathrm{c}$ & $324.5 \mathrm{c}$ & $60 c$ \\
\hline Root & $23.2 \mathrm{~b}$ & $101.1 \mathrm{~b}$ & $41.2 \mathrm{~b}$ & $15.5 \mathrm{~b}$ & $422.1 \mathrm{~b}$ & $620.2 \mathrm{~b}$ & $43.6 \mathrm{a}$ & $382.9 \mathrm{~b}$ & $97.2 \mathrm{~b}$ \\
\hline
\end{tabular}

${ }^{\mathrm{z}}$ Different lower-case letters within a column indicate significant difference using Tukey's Honest Significant Difference (HSD) test at $p$-value $\leq 0.05$.

\section{Discussion}

Increasing one nutrient from deficient level will stimulate plant growth but may eventually have a dilution effect and induce deficiency of other nutrients [33]. In this study, as $\mathrm{N}$ rate increased, 
plant biomass increased [8] and there was a dilution effect on macronutrients indicated by decreasing trends in root and average plant $\mathrm{P}$ concentrations, stem and root $\mathrm{K}$ concentrations, stems $\mathrm{Ca}$, and stem $\mathrm{Mg}$ concentrations. However, average plant $\mathrm{Ca}$ and $\mathrm{Mg}$ concentrations had increasing trends with greater $\mathrm{N}$ rate. Average plant $\mathrm{K}$ and $\mathrm{P}$ concentrations were similar among $\mathrm{N}$ rates from 0 to $20 \mathrm{mM}$ and from 5 to $20 \mathrm{mM}$, respectively. This indicates lower concentrations of these nutrients in specific structures did not reach a critical deficient level or limit plant growth. Such results agree with our previous study investigating the effects of increasing $\mathrm{N}$ rate on mineral nutrient uptake of Encore ${ }^{\circledR}$ azalea 'Chiffon' [11]. Scagel et al. [34] reported a proportional increase of other nutrients with increasing $\mathrm{N}$ was not necessary in an efficient fertilization management strategy. Concentrations of all tested macro- and micro-nutrients in hydrangea plants were generally in reasonable ranges without obvious deficiencies as referenced to Bi et al., Jahromi et al., and Bryson et al. [7,14,35].

Micronutrients uptake had different trends than macronutrients, except leaf B concentration had a decreasing trend with increasing $\mathrm{N}$ rate. Concentration and content of $\mathrm{Mn}$ and Fe in each structure and in the entire plant all increased with increasing $\mathrm{N}$ rates. Average plant $\mathrm{Zn}$ and B concentrations were not affected by $\mathrm{N}$ rates. This suggests micronutrients were generally sufficient in the $\mathrm{N}$-free fertilizer applied in this study and did not become limiting factors when $\mathrm{N}$ rate was increased up to $20 \mathrm{mM}$.

Regardless of varying trends of nutrient concentrations, content of tested macro- and micro-nutrients uniformly increased with increasing $\mathrm{N}$ rates in leaves, stems, roots, or in the entire plant. In our previous study investigating plant growth affected by $\mathrm{N}$ rate, container type and irrigation frequency, dry weights of H. macrophylla 'Merritt's Supreme' in leaves, stems, roots, or the entire plant generally increased with increasing $\mathrm{N}$ rate from 0 to $20 \mathrm{mM}$ [8]. This suggests greater $\mathrm{N}$ rate increased nutrient uptake by stimulating plant biomass production and resulted in the increasing content of mineral nutrients. Meaningful evaluation of mineral nutrient uptake should not be limited by concentration or content. Instead, plant nutrient status should be evaluated in combination with plant visual quality, or flower production depending on the production goal. Vegetative growth of hydrangea plants can be improved by increasing $\mathrm{N}$ fertilizer without the need for proportional increase of other nutrients since other mineral nutrients did not become deficient or limit plant growth.

Biocontainers have various effects on plant growth in different production systems due to the unique physical and chemical properties of the construction material. The paper biocontainers used in this study had a light color and porous sidewalls compared to the black plastic containers. The porous nature of the container sidewall increased daily water use of hydrangea and azalea plants [8,11] and was believed to reduce substrate temperature due to evaporative cooling effect [23]. Such effects were reported to be beneficial for biomass production and nutrient uptake of a light feeder like azalea [32], but reduced photosynthesis and stomatal conductance of hydrangea which has a higher water requirement [8]. Hydrangea plants grown in the paper biocontainers had similar dry weights to plants grown in plastic containers [8]. In this current study, where the main effect of container type was significant, the biocontainers consistently decreased concentrations and contents of different nutrients compared to the plastic containers, suggesting biocontainers limited nutrient uptake of hydrangea plant possibly by negatively affecting plant water status. There are exceptions when the $\mathrm{N}$ rate and container type interaction was significant, and biocontainers resulted in higher $\mathrm{K}$ concentration in leaves with $15 \mathrm{mM}$ N than plastic containers, leaf Ca concentration with $20 \mathrm{mM}$, average plant $\mathrm{Mg}$ concentration with $20 \mathrm{mM} \mathrm{N}$, content of $\mathrm{Ca}$ and $\mathrm{Mg}$ in leaves and total in the plant with $20 \mathrm{mM} \mathrm{N}$. This suggests biocontainers may be beneficial for macronutrient uptake with sufficient $\mathrm{N}$ supply.

Irrigation frequency did not interact with $\mathrm{N}$ rate or container type to affect mineral nutrient uptake of hydrangea plants in this study. One irrigation per day increased nutrient concentrations of $\mathrm{P}$ in leaves and stems, $\mathrm{Ca}$ in leaves, and $\mathrm{Zn}$ in leaves, stems and averaged in the plant compared with two irrigations per day. Irrigation frequency did not affect biomass production, net photosynthetic rate, or stomatal conductance of hydrangea plants in our previous study [8]. Two irrigations per day increased substrate moisture at $5-\mathrm{cm}$ depth and increased plant growth index in the middle of the growing season compared to one irrigation per day, but decreased stem $\mathrm{N}$ concentration [8]. 
More frequent irrigations were also found to decrease uptake of $\mathrm{Zn}, \mathrm{Cu}$, and $\mathrm{B}$ in Encore ${ }^{\circledR}$ azalea 'Chiffon' and decreased uptake of P, B, and Mn in three other Rhododendron species [11,16]. One irrigation was more beneficial to azalea plants in increasing plant size, root dry weight, root length and area, and root nitrogen content, whereas irrigation frequency had less effect on plant growth of hydrangea plants $[8,11,32]$. The effect of irrigation frequency on plant growth and nutrient uptake is species dependent. Scagel et al. $[15,16]$ considered irrigation frequency to have more effect on nutrient uptake possibly through affecting nutrient availability or root's ability for nutrient absorption, but less effect on plant biomass production. Manipulating irrigation frequency may have more influence in plants sensitive to water status. Decreased leaching fraction induced by increasing irrigation frequency may not be desirable for plants because it may increase substrate EC and cause salt stress.

Allocation of nutrients is affected by the mobility of the nutrient as well as the sink source relationship of a specific nutrient within a plant $[11,33]$. In this current study, most nutrient contents, including macro- and micro-nutrients, accumulated the most in leaves, followed by roots and stems the least. The only exception was $\mathrm{Cu}$, where roots accumulated the most, leaves second, and stems the least. Macronutrients are mobile, except $\mathrm{Ca}$, and are generally accumulated in aboveground structures like leaves, whereas most micronutrients and Ca have low mobility [36,37]. However, leaves have the largest proportion of dry weight in a hydrangea plant over stems and roots, and thus become significant sinks [8]. Leaf concentrations of $\mathrm{Zn}$ and $\mathrm{Cu}$ were relatively low compared to stems, roots, or averaged in the plant. The sink-source relationship in hydrangea plants played a more important role than mobility of nutrients. Species may also differ in allocating nutrients among structures, with many Rhododendron species accumulating the most macronutrients in leaves and the most micronutrients in roots $[8,16]$.

\section{Conclusions}

Increasing $\mathrm{N}$ rate resulted in a dilution effect on macronutrient concentrations in certain structures of hydrangea plants, but did not result in a deficient level or limit plant growth. Greater $\mathrm{N}$ rate increased nutrient uptake by increasing content of all macro- and micro-nutrients in hydrangea plants, which likely resulted from stimulated plant growth by increased $\mathrm{N}$ fertilization. Biocontainers consistently decreased nutrient concentrations and contents compared to plastic containers, possibly due to its porous sidewall increasing water use. Use of the paper biocontainers in nursery production of hydrangea plants or other species with a high-water requirement will likely require higher irrigation amounts to compensate for the containers' negative effect on nutrient uptake. Less frequent irrigation was beneficial in promoting nutrient uptake of hydrangea plants, where one irrigation per day increased $\mathrm{P}$ concentrations in leaves and stems, $\mathrm{Ca}$ in leaves, and $\mathrm{Zn}$ in leaves, stems, and averaged in the plant. Altering irrigation frequency may affect plant nutrient uptake differently among species with varied water requirements.

Supplementary Materials: The following are available online at http:/www.mdpi.com/2073-4441/12/7/1987/s1, Figure S1: Concentrations ( $\mathrm{mg} \mathrm{g}^{-1}$ ) and contents (mg per plant) of phosphorus (P) in leaves, stems, roots, or the entire plant of H. macrophylla 'Merritt's Supreme' affected by the main effect of nitrogen (N) rate, Figure S2: Concentrations $\left(\mu \mathrm{g} \mathrm{g}^{-1}\right)$ and contents ( $\mu \mathrm{g}$ per plant) of iron $(\mathrm{Fe})$ in leaves, stems, roots, or the entire plant of H. macrophylla 'Merritt's Supreme' affected by the main effect of nitrogen $(\mathrm{N})$ rate, Figure S3: Concentrations $\left(\mu \mathrm{g} \mathrm{g}^{-1}\right)$ and contents ( $\mu \mathrm{g}$ per plant) of manganese $(\mathrm{Mn})$ in leaves, stems, roots, or the entire plant of H. macrophylla 'Merritt's Supreme' affected by the main effect of nitrogen $(\mathrm{N})$ rate $(\mathrm{A}-\mathrm{F}$, and $\mathrm{H})$ or by the interaction between $\mathrm{N}$ rate and container type $(\mathrm{G})$, Figure S4: Concentrations $\left(\mu \mathrm{g} \mathrm{g}^{-1}\right)$ and contents ( $\mu \mathrm{g}$ per plant) of zinc $(\mathrm{Zn})$ in leaves, stems, roots, or the entire plant of $H$. macrophylla 'Merritt's Supreme' affected by the main effect of nitrogen (N) rate, Figure S5: Concentrations ( $\mu \mathrm{g} \mathrm{g}^{-1}$ ) and contents ( $\mu \mathrm{g}$ per plant) of boron (B) in leaves, stems, roots, or the entire plant of H. macrophylla 'Merritt's Supreme' affected by the main effect of nitrogen (N) rate (A, B, and D-H) or by the interaction between $\mathrm{N}$ rate and container type (C), Table S1: Formula of the N-free fertilizer applied to H. macrophylla plants. 
Author Contributions: T.L. and G.B. designed and set up experiments; T.L. and X.Z. carried out experiments and analyzed experimental results; G.B., R.L.H., and C.S. provided essential instruments and technical guidance; T.L. wrote the manuscript which was revised and approved by G.B., R.L.H., C.S. and X.Z. All authors have read and agreed to the published version of the manuscript.

Funding: This research received no external funding.

Acknowledgments: This work was supported by the Mississippi Agriculture and Forestry Experiment Station and the United States Department of Agriculture (USDA) National Institute of Food and Agriculture Hatch projects MIS-249180 and MIS-112040. The authors would like to thank Oregon Hydrangea Company, Brookings, OR and Natchez Trace Greenhouse, Kosciusko, MS for plant material. Mention of a trademark, proprietary product, or vendor does not constitute a guarantee or warranty of the product by Mississippi State University or the USDA and does not imply its approval to the exclusion of other products or vendors that also may be suitable.

Conflicts of Interest: The authors declare no conflict of interest.

\section{References}

1. Orozco-Obando, W.; Hirsch, G.N.; Wetzstein, H.Y. Genotypic variation in flower induction and development in Hydrangea macrophylla. HortScience 2005, 40, 1695-1698. [CrossRef]

2. Reed, S.M.; Jones, K.D.; Rinehart, T.A. Production and characterization of intergeneric hybrids between Dichroa febrifuga and Hydrangea macrophylla. J. Am. Soc. Hort. Sci. 2008, 133, 84-91. [CrossRef]

3. Van Gelderen, C.J.; van Gelderen, D.M. Encyclopedia of Hydrangeas; Timber Press: Portland, OR, USA, 2004.

4. Dirr, M.A. Hydrangeas for American Aardens; Timber Press: Portland, OR, USA, 2004.

5. U.S. Department of Agriculture. 2012 Census of Agriculture. Census of Horticultural Specialties (2014). Available online: http://www.agcensus.usda.gov/Publications/2012/Online_Resources/Census_ of_Horticulture_Specialties/HORTIC.pdf (accessed on 27 May 2020).

6. $\quad \mathrm{Bi}, \mathrm{G}$; Scagel, C.F. Nitrogen uptake and mobilization by hydrangea leaves from foliar-sprayed urea in fall depend on plant nitrogen status. HortScience 2008, 43, 2151-2154. [CrossRef]

7. Bi, G.; Scagel, C.F.; Harkess, R.L. Rate of nitrogen fertigation during vegetative growth and spray application of urea in the fall alters growth and flowering of florists' hydrangeas. HortScience 2008, 43, 472-477. [CrossRef]

8. Li, T.; Bi, G.; Harkess, R.L.; Denny, G.C.; Scagel, C. Nitrogen fertilization and irrigation frequency affect hydrangea growth and nutrient uptake in two container types. HortScience 2019, 54, 167-174. [CrossRef]

9. Millard, P. Internal cycling of nitrogen in trees. Acta Hort. 1995, 383, 3-13. [CrossRef]

10. Sanchez, E.E.; Righetti, T.L.; Sugar, D.; Lombard, P.B. Recycling of nitrogen in field-grown 'Comice' pears. J. Hort. Sci. 1991, 66, 479-486. [CrossRef]

11. Li, T.; Bi, G.; Harkess, R.L.; Blythe, E.K. Mineral nutrient uptake of Encore Azalea 'Chiffon' affected by nitrogen, container, and irrigation frequency. HortScience 2019, 54, 2240-2248. [CrossRef]

12. Gastal, F.; Lemaire, G. N uptake and distribution in crops: An agronomical and ecophysiological perspective. J. Exp. Bot. 2002, 53, 789-799. [CrossRef]

13. O'Meara, L.; Chappell, M.R.; van Iersel, M.W. Water use of Hydrangea macrophylla and Gardenia jasminoides in response to a gradually drying substrate. HortScience 2014, 49, 493-498. [CrossRef]

14. Jahromi, N.B.; Walker, F.; Fulcher, A.; Altland, J.; Wright, W.C. Growth response, mineral nutrition, and water utilization of container-grown woody ornamentals grown in biochar-amended pine bark. HortScience 2018, 53, 347-353. [CrossRef]

15. Scagel, C.F.; Bi, G.; Fuchigami, L.H.; Regan, R.P. Effects of irrigation frequency and nitrogen fertilizer rate on water stress, nitrogen uptake, and plant growth of container-grown rhododendron. HortScience 2011, 46, 1569-1603. [CrossRef]

16. Scagel, C.F.; Bi, G.; Fuchigami, L.H.; Regan, R.P. Irrigation frequency alters nutrient uptake in container-grown Rhododendron plants grown with different rates of nitrogen. HortScience 2012, 47, 189-197. [CrossRef]

17. Beeks, S.A.; Evans, M.R. Growth of cyclamen in biocontainers on an ebb-and-flood subirrigation system. HortTechnology 2013, 23, 173-176. [CrossRef]

18. Conneway, R.; Verlinder, S.; Koeser, A.K.; Evans, M.; Schnelle, R.; Anderson, V.; Stewart, J.R. Use of alternative containers for long- and short-term greenhouse crop production. HortTechnology 2015, 25, 26-34. [CrossRef]

19. Koeser, A.; Kling, G.; Miller, C.; Warnock, D. Compatibility of biocontainer in commercial greenhouse crop production. HortTechnology 2013, 23, 149-156. [CrossRef] 
20. Kratsch, H.A.; Schrader, J.A.; McCabe, K.G.; Srinivasan, G.; Grewell, D.; Graves, W.R. Performance and biodegradable in soil of novel horticulture containers made from bioplastics and biocomposites. HortTechnology 2015, 25, 119-131. [CrossRef]

21. Kuehny, J.S.; Taylor, M.; Evans, M.R. Greenhouse and landscape performance of bedding plants in biocontainers. HortTechnology 2011, 21, 155-161. [CrossRef]

22. Li, T.; Bi, G.; Niu, G.; Nambuthiri, S.S.; Geneve, R.L.; Wang, X.; Fernandez, T.; Sun, Y.; Zhao, X. Feasibility of using biocontainers in a pot-in-pot system for nursery production of river birch. HortTechnology 2015, 25, 57-62. [CrossRef]

23. Nambuthiri, B.; Geneve, R.L.; Sun, Y.; Wang, X.; Fernandez, R.T.; Niu, G.; Bi, G.; Fulcher, A. Substrate temperature in plastic and alternative nursery containers. HortTechnology 2015, 25, 50-56. [CrossRef]

24. Evans, M.R.; Tayler, M.; Kuehny, J. Physical properties of biocontainer for greenhouse crops production. HortTechnology 2010, 20, 549-555. [CrossRef]

25. Flax, N.J.; Currey, C.J.; Schrader, J.A.; Grewell, D.; Graves, W.R. Commercial greenhouse growers can produce high-quality bedding plants in bioplastic-based biocontainers. HortTechnology 2017, 27, 472-481. [CrossRef]

26. Flax, N.J.; Currey, C.J.; Schrader, J.A.; Grewell, D.; Graves, W.R. Coconut coir and peat biocontainers influence plant growth retardant drench efficacy. HortTechnology 2018, 28, 370-377. [CrossRef]

27. Evans, M.R.; Hensley, D.L. Plant growth in plastic, peat, and processed poultry feather fiber growing containers. HortScience 2004, 39, 1012-1014. [CrossRef]

28. Evans, M.R.; Karcher, D. Properties of plastic, peat, and processed poultry feather fiber growing containers. HortScience 2004, 39, 1008-1011. [CrossRef]

29. Evans, M.R.; Koeser, A.K.; Bi, G.; Nambuthiri, S.; Geneve, R.; Lovell, S.T.; Stewart, J.R. Impact of biocontainers with and without shuttle trays on water use in the production of a containerized ornamental greenhouse crop. HortTechnology 2015, 25, 35-41. [CrossRef]

30. Koeser, A.; Lovell, S.T.; Evans, M.; Stewart, J.R. Biocontainer water use in short-term greenhouse crop production. HortTechnology 2013, 23, 215-219. [CrossRef]

31. Wang, X.; Fernandez, R.T.; Cregg, B.M.; Auras, R.; Fulcher, A.; Cochran, D.R.; Niu, G.; Sun, Y.; Bi, G.; Nambuthiri, S.; et al. Multistate evaluation of plant growth and water use in plastic and alternative nursery containers. HortTechnology 2015, 25, 42-49. [CrossRef]

32. Li, T.; Bi, G.; Harkess, R.L.; Denny, G.C.; Blythe, E.K.; Zhao, X. Nitrogen rate, irrigation frequency, and container type affect plant growth and nutrient uptake of encore azalea 'Chiffon'. HortScience 2018, 53, 560-566. [CrossRef]

33. Marschner, H. Mineral Nutrition of Higher Plants, 3rd ed.; Academic Press: San Diego, CA, USA, 2012.

34. Scagel, C.F.; Bi, G.; Fuchigami, L.H.; Regan, R.P. Nitrogen availability alters mineral nutrient uptake and demand in container-grown deciduous and evergreen rhododendron. J. Environ. Hort. 2008, 26, 177-187.

35. Bryson, G.M.; Mills, H.A.; Sasseville, D.N.; Jones, J.B., Jr.; Barker, A.V. Plant Analysis Handbook III; Micro-Macro Publishing: Athens, GA, USA, 2014; p. 491.

36. Barker, A.V.; Pilbeam, D.J. Handbook of Plant Nutrition; CRC Press: Boca Raton, FL, USA, 2007.

37. Strik, B.C. Seasonal variation in mineral nutrient content of primocane-fruiting blackberry leaves. HortScience 2015, 50, 540-545. [CrossRef]

(C) 2020 by the authors. Licensee MDPI, Basel, Switzerland. This article is an open access article distributed under the terms and conditions of the Creative Commons Attribution (CC BY) license (http://creativecommons.org/licenses/by/4.0/). 